\title{
PENEMUAN MUHAMMAD BIN MUSA AL KHAWARIZMI
}

\author{
Aldewo Dillon Perkasa ${ }^{1}$, Mohammad Luthfan Faohan ${ }^{2}$, Kania Dewi $^{3}$, Galuh Inti Aulia ${ }^{4}$ \\ , Hisny Fajrusallam ${ }^{5}$

\begin{abstract}
This study aims to examine the findings of an Islamic scientist named Al Khwarizmi or better known as "Al Jabar", about the implementation and development of his mindset towards technological life today. And Islam gave birth to many figures and scientists who gave great influence and contribution to every development of science. Including Al-Khwarizmi as a scientist who is known in the field of mathematics. And work in other worlds of science. Education also proves that expertise is not only in the field of sharia but in the fields of philosophy, logic, arithmetic, music, Islamic history and chemistry. By giving his contribution Alkawarizmi caused the civilized phase until now in the developed world because of the results of his research. And he has earned the caliph's trust, until research says Alkhwarizmi is the "Father of Al-Jabar" in the world of this monumental science.
\end{abstract}

Keywords: Scientist, Al-Khwarizmi, Mathematics, Islam

Abstrak - Penelitian ini bertujuan untuk menelaah penemuan - penemuan dari seorang ilmuan Islam yang bernama Al Khawarizmi atau lebih dikenal sebagai "Al Jabar", tentang implementasi dan perkembangan pola pikirnya terhadap kehidupan berteknologi pada masa sekarang. Dan Islam melahirkan banyak tokohtokoh serta ilmuwan yang memberi pengaruh dan kontribusi besar setiap perkembangan ilmu pengetahuan. Termasuk Al-Khawarizmi sebagai ilmuwan yang dikenal dibidang matematika. Dan berkarya dalam dunia ilmu pengetahuan yang lain. Pendidikan juga membuktikan bahwasanya Keahlian bukan sekedar bidang syari at saja akan tetapi dalam bidang filsafah, logikam, aritmatika musik, Sejarah Islam dan kimia. dengan memberikan kontribusinya Alkawarizmi menyebabkan fase beradapan hingga sampai sekarang didunia yang maju karena hasil penelitiannya. Dan beliau telah mendapatkan kepercayaan Khalifah, Hingga riset mengatakan Alkhawarizmi ini sebagai "Bapak Al-Jabar" di dunia ilmu pengetahuan yang fonumental tersebut.

Kata kunci : Ilmuwan, Al-Khawarizmi, Matemaika, Islam

\section{PENDAHULUAN}

Muhammad ibn Musa al-Khawarizmi alias Algoritma ialah seorang intelektual dari abad ke-8 hingga ke-9 abad yang memberikan kontribusi signifikan terhadap perkembangan aljabar (Evans, 2014). Al-Khawarizmi adalah lahir pada tahun 783 M di Khwarizm di Persia di Asia Barat Daya, yang saat ini menjadi kota Khiva di Uzbekistan (Aksoy, 2016; Stewart, 2017). Al-Khawarizimi sangat berpengaruh dalam perkembangan aljabar di seluruh Barat Daya dan Asia Tengah, Afrika Utara, dan Eropa, yang kemudian mempengaruhi perkembangan aljabar dan matematika abad pertengahan dan modern di seluruh dunia. Dia akan melayani instruktur aljabar sekolah menengah atau perguruan tinggi dengan sangat baik untuk dapat memberikan sebagian dari ini pengetahuan sejarah kepada siswa di kelas. Penulis tertarik untuk berbagi latar belakang tentang alKhawarizmi dengan guru matematika lainnya karena diyakini ini akan membuat matematika lebih menarik dan menarik bagi siswa, yang dapat menyebabkan tingkat prestasi yang lebih tinggi bagi siswa bersama 
dengan peningkatan apresiasi atas kontribusi matematika Persia.

Al-Khawarizmi hidup pada zaman yang disebut masa kejayaan Islam, pada abad ke delapan dan abad ke 13 (Evans, 2014; Faruqi, 2015). Berkontribusi pada Zaman Keemasan Persia, al-Khawarizmi memimpin orang yang sangat saleh dan intelektual kehidupan keagamaan (Faruqi, 2015). Pada 830 M, ia mulai belajar pada naungan pemerintahan Khalifah al Ma'mun, pada pemerintahan yakni mulai pada tahun 813 hingga 833 M (Ramsden, 2017). Studi AlKhawarizmi berlangsung di BaytalHikma, atau Rumah Kebijaksanaan, di Baghdad (Stewart, 2017). Rumah Kebijaksanaan, didirikan oleh alMa'mun, berisi perpustakaan penelitian dan observatorium tempat banyak sarjana belajar (Aksoy, 2016). AlMa'mun membayangkan Rumah Kebijaksanaan sebagai tempat di mana semua teks Yunani dapat diterjemahkan ke dalam bahasa Arab dan atau Persia (Aksoy, 2016). Bagdad menjadi lokasi pusat ilmu pengetahuan dan perdagangan, yang menarik banyak sarjana kebanyakan dari Persia dan sejauh Cina dan India (Stewart, 2017).

Al-Khawarizmi menjelaskan cara penjumlahan, pengurangan, perkalian, dan pembagian menggunakan sistem bilangan ini(Gillispie et al., 2008). AlKhawarizmi memberikan solusi sebagai langkah berurutan, sehingga memperkenalkan konsep algoritma dan dengan demikian mengarah pada penciptaan kata algoritma pendahulu untuk hari ini komputasi (Aksoy, 2016). Kata "Algorithmi" dalam judul Latin karya tersebut dikenal sebagai "Algorismi" dan metode matematika menggunakan sistem angka seperti yang dijelaskan dalam pekerjaan menjadi dikenal sebagai "algorisme" (Stewart, 2017). Di antara orang Eropa, ungkapan "dixit Algorismi," atau "dengan demikian berbicara al-Khawarizmi" menjadi titik perdebatan dalam ketidaksepakatan matematis untuk mengirim pesan bahwa setiap kata yang ditulis oleh al-Khawarizmi adalah final, benar, dan harus diikuti, tidak dibantah (Stewart, 2017)

Dalam hubungannya dengan solusi aljabar dari persamaan dalam buku alKhawarizmi, ada bukti geometris (Aksoy, 2016). Al-Khawarizmi adalah sarjana pertama yang memberikan bukti geometris untuk persamaan kuadrat (Aksoy, 2016). Ide-ide orisinal AlKhawarizmi dalam teks ini, seperti yang berkaitan dengan geometri, diyakini terinspirasi oleh Elemen Euclid (Ramsden, 2017). Dalam semua matematikanya teks, al-Khawarizmi tidak menggunakan simbol matematika standar yang kita gunakan saat ini (Stewart, 2017). Ekspresi dan solusi dideskripsikan secara verbal dalam kalimat tanpa simbol. Al-Khawarizmi menggunakan kata "satuan" untuk menggambarkan suatu bilangan, " $x$ " atau untuk menggambarkan akar, dan kata kuadrat "Morabba" untuk menggambarkan x (Aksoy, 2016). Misalnya, persamaan $\mathrm{x} 2+\mathrm{x}=12$ akan dinyatakan sebagai "kuadrat ditambah akar sama dengan dua belas" unit" (Stewart, 2017, hlm. 31). Dalam persamaannya, al-Khawarizmi hanya menggunakan bilangan bulat, dan solusinya hanya memasukkan angka positif (Aksoy, 2016).

Muhammad ibn Musa al-Khawarizmi alias Algoritma ialah seorang intelektual dari abad ke-8 hingga ke-9 abad yang memberikan kontribusi signifikan terhadap perkembangan aljabar (Evans, 2014). Al-Khawarizmi adalah lahir pada tahun 783 M di Khwarizm di Persia di Asia Barat Daya, yang saat ini menjadi kota Khiva di Uzbekistan (Aksoy, 2016; Stewart, 2017). Al-Khawarizimi sangat berpengaruh dalam perkembangan 
aljabar di seluruh Barat Daya dan Asia Tengah, Afrika Utara, dan Eropa, yang kemudian mempengaruhi perkembangan aljabar dan matematika abad pertengahan dan modern di seluruh dunia. Dia akan melayani instruktur aljabar sekolah menengah atau perguruan tinggi dengan sangat baik untuk dapat memberikan sebagian dari ini pengetahuan sejarah kepada siswa di kelas. Penulis tertarik untuk berbagi latar belakang tentang alKhawarizmi dengan guru matematika lainnya karena diyakini ini akan membuat matematika lebih menarik dan menarik bagi siswa, yang dapat menyebabkan tingkat prestasi yang lebih tinggi bagi siswa bersama dengan peningkatan apresiasi atas kontribusi matematika Persia.

Al-Khawarizmi adalah ulama di Rumah Kebijaksanaan di Baghdad. Tugasnya adalah menafsirkan suatu naskah ilmiah Yunani. Dia juga belajar dan menulis banyak buku dan risalah. Aljabarnya adalah buku pertama tentang penyelesaian secara terstruktur persamaan linear dan kuadrat. Maka dari itu, Al-Khawarizmi dianggap sebagai bapak aljabar, gelar yang dia bagikan dengan Diophantus. Terjemahan Latin dari Aritmatikanya, pada angka India, memperkenalkan sistem angka posisi desimal ke dunia Barat pada abad ke-12. Dia merevisi dan memperbarui Geografi Ptolemy juga menuliskan berbagai karya mengenai astrologi juga astronomi. Keikutsertaan nya juga tidak hanya membuat pengaruh yang besar pada matematika, melainkan terhadap Bahasa juga. Al-jabr atau al-jabar, merupakan salah satu dari 2 metode yang digunakan untuk menyelesaikan sebuah persamaan kuadrat, dimana telah dijelaskan dalam sebuah buku buku tersebut. Kata algorism dan algoritma berasal dari algoritmi. Nama tersebut berasal dari kata Spanyol guarismo dan kata Portugis algarismo, dari kedua hal tersebut memiliki arti yang sama yakni angka.

Kontribusi utamanya pada geografi, astrologi, astronomi, matematika, dan kartografi memberikan dasar atau landasan untuk terobosan selanjutnya dan bahkan lebih luas dalam trigonometri juga aljabar dan bidang minatnya yang lain. Pendekatan sistematis dan logisnya yang berguna sebagai memecahkan persamaan kuadrat serta linear memberikan bentuk pada disiplin aljabar, sebuah kata yang berasal dari nama 830 bukunya tentang masalah ini, al-Kitab al-mukhtasar fi hisab al-jabr wa'l- muqabala atau: "Buku Komprehensif tentang Perhitungan dengan Penyelesaian dan Penyeimbangan". Buku ini pertama kali diterjemahkan ke dalam bahasa Latin pada abad kedua belas.Bukunya On the Calculation with Hindu Numerals yang ditulis sekitar tahun 825, dengan pertanggung jawaban yang dimana penyebaran penomoran India di Timur Tengah dan kemudian Eropa. Buku ini juga diartikan ke dalam bahasa Latin pada abad ke 12, sebagai Algoritmi de numero Indorum. Dari nama penulisnya, yang diterjemahkan dalam bahasa Latin sebagai algoritmi, muncullah istilah algoritme. Beberapa kontribusinya didasarkan pada Astronomi Persia dan Babilonia sebelumnya, angka-angka India, dan sumber-sumber Yunani.

Muhammad bin Musa al- Khawarizmi memiliki beragam hasil penelitian dengan hasik karya ilmiah serta buku yang beliau terbitkan dan buat sangat berragam. Banyaknya buku didang ilmu al-kwarizmi yang ditulis yakni sebanya kurang lebih lima puluh buku, yang kebanyakan dari buku yang telah ia buat banyak yang hilang serta riset sebuah ilmiah yang Al-Khwarizmi kerjakan. AlKhawarizmi juga sering mendapatkan amanat dari pemimpin untuk melaksanakan rihlah ilmiah, 
mengadakan riset berupa suatu ilmiah serta berbagai tugas inti. Di antara para pemimpin yakni al-Watsiq mengintruksikan kepada al-Khawarizmi untuk membuat sebuah observasi mengenai jasad Ashabul Kahfi yang telah dicantumkan pada al-Qur'an bahwasannya jasad itu tersebut dengan bentukan utuh didalam Gua, yang dimana seperti jasad yang mau mati. Pemimpin al-Watsiq ingin membuktikan akan kebenaran dari cerita yang di informasikan dalam al-Qur'an serta tujuannya ialah dia menugasi alKhawarizmi. Ia datang ke Romawi sekaligus menjumpai para pembesar Romawi. Yang kemudian memberikan tugas akan penunjuk jalan untuk mengiringi menuju gua yang letaknya berada pada puncak gunung kecil. Dari hal tersebut al-Khawarizmi melihat jasad dari puncak gunung kecil. Kemudian kembali ke Khalifah al Watsiq dengan berita bahwa, "Ashabul Kahfi mati seperti biasanya, akan tetapi jasad mereka diawetkan dengan balsem dan kapur".

\section{METODE PENELITIAN}

Suatu karya sejarah yang bermutu ada beberapa Langkah yang dapat digunakan yang gunanya untuk pemulihan atau perbaikan Kembali untuk mengulik masa lampau. Penulisan sejarah tersebut mempunyai suatu langkah tersendiri untuk mengetahui suatu akan adanya suau kejadian pada masa lampau untuk menghasilkan sebuah karya sejarah yang sifatnya ilmiah, logis, objektif, kritis. Sejarah menurut Nugroho Notosusanto memiliki 4 kegiatan dalam tahapan yakni:

\section{A. Heuristik}

Heuristik berasal dari kata Heurikein yang berarti memperoleh atau menemukan. Heuristik disini merupakan kegiatan menghimpun jejak-jejak masa lampau yang dikenal sebagai data-data sejarah. Dalam melakukan kegiatan menghimpun jejak atau data-data sejarah, 16 Nugroho Notosusanto, Norma-norma Dasar Penelitian Penulisan Sejarah. Jakarta: Dephankam, 1971, hlm.35. Dalamlangkah ini Penulis berusaha mencari akan beberapa sumber yang sesuai dan benar yang tujuannnya untuk dijadikan bahan dari kajian yang gunanya untuk penyusunan sebuah makalah ini. Pengumpulan sumber atau yang dapat disebut Heurisik merupakan sebuah kegiatan untuk mendapatkan sumber-sumber yang digunakan dalam penulisan makalah ini, seperti; jurnal, majalah dan buku.

\section{B. Kritik Sumber}

Kritik sumber dikerjakan bertujuan untuk penentu akan data atau sumber yang didapatkan apakah sudah sesuai serta dapat dipertanggung jawabkan akan suatu kebenarannya baik secara fisik maupun kasat mata. Kritik sumber memiliki bebberapa aspek yakni dari kritik ekstern dan kritik intern, dimana Kritik ekstern tersebut dilakukan yang tujuannnya untuk mengetahui akan pengujian dokumen tersebut asli atau tidak jika dokumen tersebut dilihat dari segi tulisan, bahan, bentuk, dan lain sebagainya. Sedangkan jika kritik intern tersebut dilakukan yang tujuannya untuk mengetahui suatu urusan atau kegiatan memiliki keterikatan akan suatu pembahasan yang dimana kaitannya dengan isi dari sumber tersebut apakah dapat teruji kebenarannya.

\section{Interpretasi}

Penafsiran atau Interpretasi merupakan subuah kegiatan dengan menerjemahkan dari sebuat fakta 
yang kebenarannya kebenarannya telah diuji atau untuk menerjemahkan fakta yang telah didapatkan yang kemudian data tersebut dapat dianalisis, menurut I Gede Widja, Sejarah Lokal dalam Pengajaran Sejarah. Jakarta: Departemen Pendidikan dan Kebudayaan, 1989, hlm.18. 20 mewujudkan akan kumpulan suatu kejadian. Penerjemahan berbagai data, didapat berdasarkan kekuatan akan analisis yang dapat diperkuat melalui kajian pustaka dan segi pemeriksaan atau kontrol seperti ( psikologi, polotik serta sosial)

D. Historiografi (Penulisan Sejarah) Suatu aktivitas dalam penyusunan dari berbagai fakta yang dijadikan sejarah atau dapat disebut Historiografi, setelah memenuhi akan pencarian sumber, penilaian dari sumber tersebut, penerjemahan lalu direalisasikan menjadi suatu kisah sejarah yang bentuknya menjadi tulisan. Sudut pandang akan suatu kejadian yang berkesinambungan merupakan suatu hal sangat penting dalam penulisan sejarah karena bertujuan untuk mengetahui suatu sistematika dari perkembangan dan perubahan yang terjadi dalam suatu kejadian atau peristiwa sejarah.

E. Sistematika Pembahasan

Sistematika Pembahasan Untuk memperoleh gambaran yang jelas dan menyeluruh mengenai makalah ini, maka penulis akan memberikan gambaran secara ringkas. Sistematika pembahasan dalam makalah ini adalah sebagai berikut :

\section{BAB I PENDAHULUAN}

Pada bab ini berisi latar belakang, rumusan masalah, tujuan penelitian, manfaat penelitian, kajian pustaka, metode dan pendekatan penelitian serta sistematika pembahasan.

\section{BAB II RIWAYAT HIDUP MUHAMMAD BIN MUSA AL KHAWARIZMI}

Dalam bab ini dibahas mengenai riwayat hidup Al-Khawarizmi dari kelahirannya sampai perjalanan hidup Al-Khawarizmi,

\section{BAB III PENEMUAN ILMIAH MUHAMMAD BIN MUSA AL KHAWARIZMI}

Pada bab ini membahas mengenai penemuan-penemuan

Khawarizmi

\section{BAB IV ANALISIS HUBUNGAN PEMIKIRAN MUHAMMAD BIN MUSA AL KHAWARIZMI DENGAN TEKNOLOGI}

Bagian ini penulis membahas tentang hubungan pemikiran AlKhawarizmi dengan Teknologi yang saat ini semakin canggih.

\section{BAB V KESIMPULAN}

Dalam bab ini berisi kesimpulan dari keseluruhan pembahasan pada bab-bab sebelumnya. Kesimpulan yang diperoleh merupakan jawaban yang menjadi pokok permasalahan dalam rumusan masalah.

\section{HASIL DAN PEMBAHASAN}

Teknologi modern merupakan bidang lain yang mengalami akan manfaat dari kontribusi Al-Khawarizmi. Seperti yang telah diberitahu oleh Dr Ibrahim B Syed (2011), dimana algoritma juga aljabar yang dimana dari sebuah tersebutlah yang algoritma menjadikan kemungkinan akan pencetus awal dari sebuah teknologi yang dinamakan dengan komputer juga pembuatan enkripsi. Ia beranggapan bahwa, industri pada bidang teknologi modern tidak akan ada tanpa adanya sebuah pengkontribusian matematikawan yang notabennya Muslim, yaitu alKhawarizmi. Pada sebuah karya tulis yang memiliki judul "Al- Khwarizmi: 
The Father of Algebra", Syed mengutarakan perihal abad ke-11, dimana permulaan dari matematika Arab ialah salah satu yang terkuat pada kalangan dunia. Al-Khawarizmi merupakan salah seorang sarjana Muslim yang menaruh dasar bagi renaisans serta peredaran Ilmiah yang berasal dari Eropa. Al-Khawarizmilah merupakan seorang yang pertamakali menemukan aljabar geometri juga membawanya ke tingkatan atau derajat yang canggih, serta berpengalaman dalam memberikan solusi akan persamaan derajat ketiga dan keempat. Penafsiran berbagai karya tidak hanya menerjemahkan pada 1 bahasa saj melainkan meneremahkan dari berbagai Bahasa seperti Bahasa Arab dan Bahasa Eropa hal tersebutlah yang merupakan salah satu pembantu dunia akan menyaksikan akan pada jenjang pembaharuan dalam salah satu pengembangan ilmu yang tentunya pada bidang matematika tersebut. Oleh karena itu, penemuan Al-Khawarizmi awalnya tidak langsung diterima oleh dunia. Misalnya Pada tahun 1299, hukum yang berada pada daerah Florence (Italia) tidak menyetujui akan penggunaan angka yang ditemukan serta dikembangkan oleh Al-Khawarizmi sehingga hanya ada beberapa sekolah tinggi yang berani memakai perkembangan tersebut. Meski demikian, pengaruh terhadap pengembangan ilmu pengetahuan di bagian Barat merupakan ciri yang tidak selayaknya terhapuskan karena kary tersebut dikenal luas oleh negara Eropa melalui penerjemahannya kedalam bahasa Latin. Setelah diperkenalkan di Eropa, karyanya menjadi teks standar matematika di universitas-universitas Eropa hing ga abad ke-16. Pada abad yang sama, versi terjemahan dalam bahasa Inggris me munculkan istilah 'algiebar', 'almachabel', serta bentuk penamaan lainnya. Yang pada akhirnya, istilah tersebut dipersingkat menjadi 'algebra' atau aljabar. Sejumlah sumber yang diambil Erwyn Kurniawan pada sebuah artikel "Al-Khawarizmi: Penemu Bilangan Nol" (esq-news.com) memaparkan bahwa, ilmu pada bidang matematika di dunia bagian Barat lebih terpengaruh oleh karya Al- Khawarizmi dibandingkan karya para penulis

\section{KESIMPULAN DAN SARAN}

Kesimpulan dari penelitian ini yaitu, secara garis besar $\mathrm{Al}$ - Khawarizmi atau yang lebih dikenal sebagai Al Jabar lahir pada tahun $783 \mathrm{M}$ di Khwarizm di Persia di Asia Barat Daya, yang saat ini menjadi kota Khiva di Uzbekistan (Aksoy, 2016; Stewart, 2017). AlKhawarizimi sangat berpengaruh dalam perkembangan aljabar di seluruh Barat Daya dan Asia Tengah, Afrika Utara dan Eropa, yang kemudian mempengaruhi perkembangan aljabar dan matematika abad pertengahan dan modern di seluruh dunia. Al-Khawarizmi menjelaskan cara penjumlahan, pengurangan, perkalian, dan pembagian menggunakan sistem bilangan ini Al-Khawarizmi memberikan solusi sebagai langkah berurutan, sehingga memperkenalkan konsep algoritma dan dengan demikian mengarah pada penciptaan kata algoritma pendahulu untuk hari ini komputasi (Aksoy, 2016). Dalam hubungannya dengan solusi aljabar dari persamaan dalam buku al-Khawarizmi, ada bukti geometris

Muhammad bin Musa al- Khawarizmi memiliki beragam hasil penelitian dengan hasik karya ilmiah serta buku yang beliau terbitkan dan buat sangat berragam. Banyaknya buku didang ilmu al-kwarizmi yang ditulis yakni sebanya kurang lebih lima puluh buku, yang kebanyakan dari buku yang telah ia buat banyak yang hilang serta riset sebuah ilmiah yang Al-Khwarizmi kerjakan. Al- 
Khawarizmi juga sering mendapatkan amanat dari pemimpin untuk melaksanakan rihlah ilmiah, mengadakan riset berupa suatu ilmiah serta berbagai tugas inti.

Muhammad bin Musa al- Khawarizmi mengutip angka-angka India dan mengarang sebuah buku tentang angkaangka itu, serta membuat buku dalam ilmu hitung dengan memberikan babbab di dalamnya, yang buku itu tidak pernah ada sebelumnya. al-Kitab almukhtașar fi hisab al-jabr wa-lmuqabala "Buku Ringkas tentang Perhitungan dengan Penyelesaian dan Penyeimbangan") merupakan salah satu buku pada bidang matematika yang ia tulis sekitar tahun $830 \mathrm{M}$. Kata tersebut diambil berdasarkan nama salah satu operasi dasar dengan persamaan (al-jabr) juga ada pada buku tersebut Aritmetika Karya besar kedua Al-Khawarizmi adalah tentang aritmatika, yang bertahan dalam terjemahan Latin tetapi hilang dalam bahasa Arab asli. Algoritma adalah salah satu dari cabang ilmu matematika, kata algoritma berasal dari latinisasi nama al- 73 Khawarizmi, yang tercantum dalam karyanya dalam bahasa Latin pada abad ke-12, yaitu algorithmi de numero indorum. Al-Khawarizmi adalah Kitab surat al-Ard "Buku tentang penampakan Bumi" atau "Citra Bumi" diterjemahkan sebagai Geografi), yang selesai pada 833 .

Teknologi modern merupakan bidang lain yang mengalami akan manfaat dari kontribusi Al-Khawarizmi Pada sebuah karya tulis yang memiliki judul "AlKhwarizmi: The Father of Algebra", Syed mengutarakan perihal abad ke-11, dimana permulaan dari matematika Arab ialah salah satu yang terkuat pada kalangan dunia. Al-Khawarizmi merupakan salah seorang sarjana Muslim yang menaruh dasar bagi renaisans serta peredaran Ilmiah yang berasal dari Eropa. Penafsiran berbagai karya tidak hanya menerjemahkan pada 1 bahasa saj melainkan meneremahkan dari berbagai Bahasa seperti Bahasa Arab dan Bahasa Eropa hal tersebutlah yang merupakan salah satu pembantu dunia akan menyaksikan akan pada jenjang pembaharuan dalam salah satu pengembangan ilmu yang tentunya pada bidang matematika tersebut.

\section{DAFTAR PUSTAKA}

Maula, I., Pambudi, A. S., \& Rohmah, Z. (2018). Perkembangan Matematika dalam Sejarah Peradaban Islam. Prosiding Konferensi Integrasi Interkoneksi Islam dan Sains, 1, 115-119.

Anwar, N. (2017). Belajar Lebih Dari Matematikawan Muslim. ITQAN: Jurnal Ilmu-Ilmu Kependidikan, 8(2), 17-33.

Rashed, R. (2014). Classical mathematics from alKhwarizmi to Descartes. Routledge.

Van der Waerden, B. L., Artin, E., \& Noether, E. (1950). Moderne algebra (Vol. 31950). Berlin: Springer.

Arndt, A. B. (1983). Al-Khwarizmi. The Mathematics Teacher, 76(9), 668-670.

Kurnia, R. A. E. (2011). Teori Aljabar Al-Khawarizmi. Jurisdictie.

Ardiansyah, L. (2013). Pemikiran Ibnu Khaldun Tentang Pendidikan (Doctoral dissertation, Tesis Sarjana, Universitas Negeri Yogyakarta).

Setiawan, H. R. (2017). Kontribusi AlKhawarizmi Dalam Perkembangan Ilmu Astronomi. Al-Marshad: Jurnal Astronomi Islam dan Ilmu-Ilmu Berkaitan, 1(1). 